\title{
Emended Description of Paenibacillus amylolyticus and Description of Paenibacillus illinoisensis sp. nov. and Paenibacillus chibensis sp. nov.
}

\author{
OSAMU SHIDA, ${ }^{1 *}$ HIROAKI TAKAGI, ${ }^{1}$ KIYOSHI KADOWAKI, ${ }^{1}$ LAWRENCE K. NAKAMURA, ${ }^{2}$ \\ AND KAZUO KOMAGATA ${ }^{3}$ \\ Research Laboratory, Higeta Shoyu Co., Ltd., Choshi, Chiba $288,{ }^{1}$ and Department of Agricultural Chemistry, \\ Faculty of Agriculture, Tokyo University of Agriculture, Setagaya-ku, Tokyo $156,{ }^{3}$ Japan, and Microbial \\ Properties Research, National Center for Agricultural Utilization Research, \\ U.S. Department of Agriculture, Peoria, Illinois $61604^{2}$
}

The taxonomic position of unidentified group 6 of Bacillus circulans as described by Nakamura and Swezey (L. K. Nakamura and J. Swezey, Int. J. Syst. Bacteriol. 33:46-52, 1983) was determined, and the taxonomy of Paenibacillus amylolyticus was reexamined. The results of PCR amplification of a 16S rRNA gene fragment with a specific primer and comparative analysis of 16S rRNA gene sequences warranted placing the two taxa in the genus Paenibacillus. The levels of DNA reassociation among the strains revealed four groups (designated groups I, II, III, and 6), each with a high level of intragroup relatedness ( $>72 \%)$. Clustering based on phenotypic characteristics correlated well with DNA relatedness grouping. $P$. amylolyticus strains were scattered in groups I, II, and III. Strains labeled the type strain of $P$. amylolyticus from different culture collections appeared in groups I and III. Strains found in group I were identified as $P$. amylolyticus sensu stricto, and the one strain found in group III was identified as Paenibacillus lautus. Group 6 encompassed strains formerly assigned to $B$. circulans group 6, and group II contained other strains identified as $P$. amylolyticus. Groups 6 and II were phenotypically and genetically distinct taxa that were distinguishable from the previously described species. These findings showed that groups 6 and II were new species, for which we propose the names Paenibacillus illinoisensis and Paenibacillus chibensis, respectively.

Nakamura and Swezey $(11,12)$ observed the taxonomic heterogeneity of Bacillus circulans strains and separated these organisms into B. circulans sensu stricto and nine groups at the species level. Six of these groups were reclassified as the following new Bacillus species: Bacillus amylolyticus, Bacillus lautus, Bacillus pabuli, Bacillus validus, Bacillus alginolyticus, and Bacillus chondroitinus $(13,14)$. Recently, Ash et al. proposed the transfer of $B$. amylolyticus, B. pabuli, and $B$. validus to the genus Paenibacillus (2), and Heyndrickx et al. proposed the transfer of $B$. lautus to the genus Paenibacillus (8). One of the three remaining groups, the group designated group $6(12)$ containing six strains, merited further study.

Also, anomalies noted during preliminary DNA relatedness studies prompted a reexamination of the taxonomy of the genus Paenibacillus. To clarify the taxonomic position of the group 6 strains and to reexamine the taxonomy of Paenibacillus amylolyticus, we determined the DNA base compositions, levels of DNA relatedness, phenotypic characteristics, chemosystematic properties, 16S rRNA gene sequences, and phylogenetic relationships of these organisms.

\section{MATERIALS AND METHODS}

Bacterial strains. The bacterial strains used in this study are listed in Table 1 Working stocks were cultured on tryptic soy agar (Difco Laboratories, Detroit, Mich.) plates for $24 \mathrm{~h}$ at $37^{\circ} \mathrm{C}$ and stored at room temperature.

Identification of strains at the genus level by $16 \mathrm{~S}$ rRNA gene fragment amplification. Strains in the genus Paenibacillus were identified by PCR amplification of a 16S rRNA gene fragment with specific forward primer PAEN515F (5'-GCTCGGAGAGTGACGGTACCTGAGA-3') and universal reverse primer 1377R (19). The sequence of reverse primer 1377R, PCR amplification of the 16S rRNA gene from chromosomal DNA, and detection of PCR products have been described previously $(18)$

\footnotetext{
* Corresponding author. Mailing address: Research Laboratory Higeta Shoyu Co., Ltd., 2-8 Chuo-cho, Choshi, Chiba 288, Japan. Phone: 81-479-22-1180. Fax: 81-479-24-3422. E-mail: LDX05744 @niftyserve.or.jp
}

DNA base composition and DNA relatedness. The procedures used to isolate and purify chromosomal DNA and to estimate DNA base composition were the procedures described by Takagi et al. (20). DNA relatedness values were determined as described by Ezaki et al. (4). Probes for DNA-DNA hybridization were prepared from Bacillus sp. strains NRRL NRS-1175 and NRRL NRS-1356 ${ }^{\mathrm{T}}$ ( $\mathrm{T}=$ type strain) and $P$. amylolyticus IFO $13625^{\mathrm{T}}$, NRRL B-377 ${ }^{\mathrm{T}}$, NRRL B-142 ${ }^{\mathrm{T}}$, NRRL B-14939, and NRRL NRS-290

Determining and comparing 16S rRNA gene DNA sequences. The methods used for preparation of chromosomal DNA and PCR amplification of the 16S rRNA gene from chromosomal DNA and the primers used for PCR amplification have been described previously (18). Amplified 16S rRNA genes purified with a QIAquick Spin PCR purification kit (QIAGEN GmbH, Hilden, Germany) were used for sequencing templates. Sequencing was carried out as described by Sanger et al. (16) by using a Dye terminator cycle sequencing FS Ready Reaction kit (Perkin-Elmer Co., Foster City, Calif.) and a model ABI 373A automatic DNA sequencer (Perkin-Elmer Co.). The seven sequencing primers were used as described by Fox et al. (6).

Previously published 16S rRNA gene sequences were obtained from the EMBL, GenBank, and DDBJ databases. Multiple alignment of sequences, calculation of nucleotide substitution rates ( $K_{\text {nuc }}$ values) (9), construction of a neighbor-joining phylogenetic tree (17), and a bootstrap analysis with 1,000 replicates for evaluation of phylogenetic tree topology (5) were carried out with the CLUSTAL W version 1.5 program (21). Alignment gaps and unidentified base positions were not taken into account.

Phenotypic characterization and numerical analysis. Phenotypic characterization of seven strains of Bacillus species, eight $P$. amylolyticus strains, and four Paenibacillus lautus strains was carried out as described by Gordon et al. (7) and Takagi et al. (20). The phenotypically based relationships among these 19 strain were determined by performing a numerical analysis as described previously (20).

Cellular fatty acid composition and isoprenoid quinone composition. For cellular fatty acid and isoprenoid quinone analyses, the organisms were cultivated overnight in tryptic soy broth (Difco Laboratories) at $37^{\circ} \mathrm{C}$. Preparation and determination of cellular fatty acids and isoprenoid quinones were carried out as described by Komagata and Suzuki (10).

Nucleotide sequence accession numbers. The 16S rRNA gene sequences determined in this study have been deposited in the EMBL, GenBank, DDBJ databases under the accession numbers listed in Table 1.

\section{RESULTS}

Identification of strains at the genus level by $16 \mathrm{~S}$ rRNA gene fragment amplification. The results of 16S rRNA gene fragment amplification of the seven Bacillus strains and eight 
TABLE 1. Bacterial strains used in this study

\begin{tabular}{|c|c|c|c|}
\hline Strain $^{a}$ & Source $^{b}$ & History ${ }^{a}$ & Accession no \\
\hline \multicolumn{4}{|c|}{ Bacillus circulans group 6 strains } \\
\hline NRRL NRS-1174 & 1 & H. W. Reuszer, Army strain 1324 (= HSCC 486) & \\
\hline NRRL NRS-1175 & 1 & H. W. Reuszer, Army strain 1329 (= HSCC 318) & \\
\hline NRRL NRS-1177 & 1 & H. W. Reuszer, Army strain $1376(=$ HSCC 401) & \\
\hline NRRL NRS-1343 & 1 & F. E. Clark, strain 15 , isolated from soil $(=$ HSCC 484$)$ & \\
\hline NRRL NRS- $1356^{\mathrm{T}}$ & 1 & F. E. Clark, strain $14^{\mathrm{T}}$, isolated from soil $\left(=\mathrm{HSCC} 309^{\mathrm{T}}=\mathrm{JCM} 9907^{\mathrm{T}}=\mathrm{IFO} 15959^{\mathrm{T}}\right)$ & D85397 \\
\hline IFO 15379 & 2 & NRRL NRS-1173 from H. W. Reuszer, Army strain 1304 (= HSCC 302) & \\
\hline \multicolumn{4}{|c|}{ Paenibacillus amylolyticus strains } \\
\hline NRRL NRS-290 ${ }^{\mathrm{T}}$ & 1 & Reacquired from the original NRS- $290^{\mathrm{T}}$ stock $\left(=\mathrm{HSCC} 434^{\mathrm{T}}=\mathrm{JCM} 9906^{\mathrm{T}}=\right.$ IFO $15957^{\mathrm{T}}$ ) & D85396 \\
\hline IFO $13625^{\mathrm{T}}$ & 2 & ATCC $9995^{\mathrm{T}}$ from NRS $-290^{\mathrm{T}}$ from N. R. Smith from K. F. Kellerman (= HSCC $\left.173^{\mathrm{T}}\right)$ & \\
\hline ATCC $9995^{\mathrm{T}}$ & 3 & NRS- $290^{\mathrm{T}}$ from N. R. Smith $\left(=\mathrm{HSCC} 430^{\mathrm{T}}\right)$ & \\
\hline NRRL B-14940 & 1 & ATCC $9995^{\mathrm{T}}$ from NRS- $290^{\mathrm{T}}$ from N. R. Smith, obtained in $1995\left(=\right.$ HSCC $\left.432^{\mathrm{T}}\right)$ & \\
\hline NRRL B-142 ${ }^{\mathrm{T}}$ & 1 & FDA strain PCI $221^{\mathrm{T}}\left(=\right.$ HSCC $442^{\mathrm{T}}=\mathrm{JCM} 9905^{\mathrm{T}}=$ IFO $\left.15958^{\mathrm{T}}\right)$ & D85395 \\
\hline NRRL B-14939 & 1 & ATCC 9966 from FDA strain PCI 221, obtained in 1995 (= HSCC 433) & \\
\hline NRRL NRS-359 & 1 & N. R. Smith (= HSCC 497) & \\
\hline NRRL NRS-1136 & 1 & ATCC 9966 from FDA strain PCI 221 (= HSCC 474) & \\
\hline NRRL B-377 ${ }^{\mathbf{T}}$ & 1 & NRS- $290^{\mathrm{T}}$ from N. R. Smith from K. F. Kellerman $\left(=\right.$ HSCC $374^{\mathrm{T}}=$ IFO $\left.15876^{\mathrm{T}}\right)$ & D85609 \\
\hline \multicolumn{4}{|c|}{ Paenibacillus lautus strains } \\
\hline NRRL NRS- $666^{\mathrm{T}}$ & 1 & University of Washington, "Bacillus lautus" (= HSCC $\left.493^{\mathrm{T}}\right)$ & D78473 \\
\hline NRRL NRS-678 & 1 & N. R. Smith, migratory colonies 3, isolated from soil (= HSCC 426) & \\
\hline NRRL NRS-679 & 1 & N. R. Smith, migratory colonies 4 , isolated from soil $(=$ HSCC 402$)$ & \\
\hline NRRL B-379 & 1 & NRS-676 from N. R. Smith, migratory colonies 1 , isolated from soil (= HSCC 424) & \\
\hline
\end{tabular}

${ }^{a}$ HSCC, Culture Collection of the Research Laboratory of Higeta Shoyu Co., Ltd., Chiba, Japan; JCM, Japan Collection of Microorganisms, Saitama, Japan; FDA Food and Drug Administration, Washington, D.C.; NRRL, Agricultural Research Service Culture Collection, National Center for Agricultural Utilization Research, Peoria, III.; IFO, Institute for Fermentation, Osaka, Japan; ATCC, American Type Culture Collection, Rockville, Md.

${ }^{b}$ 1, Agricultural Research Service Culture Collection, National Center for Agricultural Utilization Research, Peoria, Ill.; 2, Institute for Fermentation, Osaka, Japan; 3, American Type Culture Collection, Rockville, Md

P. amylolyticus strains studied are shown in Fig. 1. When specific forward primer PAEN515F and universal reverse primer 1377R were used, 0.8-kb PCR fragments were amplified in all 15 strains tested. These results suggested that all of the strains examined were members of the genus Paenibacillus.

DNA base compositions and DNA relatedness. The $\mathrm{G}+\mathrm{C}$ contents of the 15 strains mentioned above ranged from 46.3 to $53.2 \mathrm{~mol} \%$ (Table 2). Low levels of relatedness (range, 2 to $40 \%$ ) showed that the group 6 reference strain (NRRL NRS1356) is not closely related to the type strains of previously established Paenibacillus species (Table 3). High levels of intragroup DNA relatedness among the $B$. circulans group 6 strains (NRRL NRS-1174, NRRL NRS-1175, NRRL NRS1177, NRRL NRS-1343, NRRL NRS-1356 ${ }^{\mathrm{T}}$, and IFO 15379) (range, 78 to $100 \%$ ) demonstrated the genetic homogeneity of this distinct group (Table 2).

Because preliminary studies revealed anomalies in the DNA relatedness of $P$. amylolyticus strains, the relationships of three strains of this species to each other and to the type strains of other species were also studied (Table 3). Low levels of DNA relatedness (range, 0 to $26 \%$ ) showed that the three $P$. amylolyticus strains were not related to each other. However, a high level of DNA relatedness $(86 \%)$ was noted between NRRL B- $377^{\mathrm{T}}$ and NRRL NRS-666, the type strain of $P$. lautus.

To determine the cause of the anomalous data obtained with the $P$. amylolyticus strains, the levels of DNA relatedness of strains from several different culture collections were determined. Table 2 shows the levels of relatedness of the $P$. amylolyticus strains from several different sources. These strains were separated into three independent groups based on DNA relatedness values greater than $72 \%$. Group I encompassed the type strains of $P$. amylolyticus acquired from different sources (namely, strains IFO $13625^{\mathrm{T}}$, NRRL B-14940 ${ }^{\mathrm{T}}$, ATCC $9995^{\mathrm{T}}$ and NRRL NRS-290 ${ }^{\mathrm{T}}$ ) (Table 1). Four other P. amylolyticus strains (NRRL B-142 ${ }^{\mathrm{T}}$, NRRL B-14939, NRRL NRS-359, and
NRRL NRS-1136) made up group II. Type strain NRRL B-377 was the sole constituent of group III.

Phylogenetic relationships. The nucleotide sequences $(1,435$ to 1,440 nucleotides) of the $16 \mathrm{~S}$ rRNA gene from strains NRRL NRS- $1356^{\mathrm{T}}$, NRRL NRS-290 ${ }^{\mathrm{T}}$, NRRL B-142 ${ }^{\mathrm{T}}$, and NRRL B- $377^{\mathrm{T}}$ were determined. The sequence similarity values for strains NRRL NRS- $1356^{\mathrm{T}}$, NRRL NRS-290 ${ }^{\mathrm{T}}$, and NRRL B-142 ${ }^{\mathrm{T}}$ and 19 Paenibacillus species were greater than 90.6\%; the similarity values for strains NRRL NRS- $1356^{\mathrm{T}}$, NRRL NRS- $290^{\mathrm{T}}$, and NRRL B-142 ${ }^{\mathrm{T}}$ and the other members of the family Bacillaceae were less than $90.1 \%$ (data not shown). Strains NRRL NRS- $1356^{\mathrm{T}}$, NRRL NRS- $290^{\mathrm{T}}$, and NRRL B- $142^{\mathrm{T}}$ were placed in a robust (bootstrap value, 1,000 ) monophyletic cluster consisting of the Paenibacillus species (Fig. 2). Moreover, NRRL NRS-1356 ${ }^{\mathrm{T}}$ (a group 6 strain), $P$. amylolyticus, NRRL B-142 ${ }^{\mathrm{T}}$ (a group II strain), P. lautus, Paenibacillus glucanolyticus, Paenibacillus macquariensis, and Paenibacillus pabuli appeared to form a subgroup within the genus Paenibacillus. The $16 \mathrm{~S}$ rRNA gene from NRRL B-377 exhibited a high level of similarity $(98.7 \%)$ with the $16 \mathrm{~S}$ rRNA gene from the type strain of $P$. lautus (data not shown).

Phenotypic characterization. Because $B$. circulans group 6, $P$. amylolyticus groups I and II, and P. lautus formed a putative phylogenetic subgroup, 98 of their phenotypic characteristics were compared. The 19 strains of these species exhibited 18 differences among the characteristics tested (Table 4).

According to the results of a numerical analysis based on these differential characteristics, the $P$. amylolyticus strains tested could be separated into three clusters at a similarity level of $95 \%$; the group 6 strains also formed a discrete cluster (Fig. 3). These clusters correlated well with the groups circumscribed by DNA relatedness data.

Cellular fatty acid composition and isoprenoid quinone composition. Strains NRRL NRS-1175 and NRRL NRS-1356 in group 6, strains IFO $13625^{\mathrm{T}}$ and NRRL NRS-290 ${ }^{\mathrm{T}}$ in group 

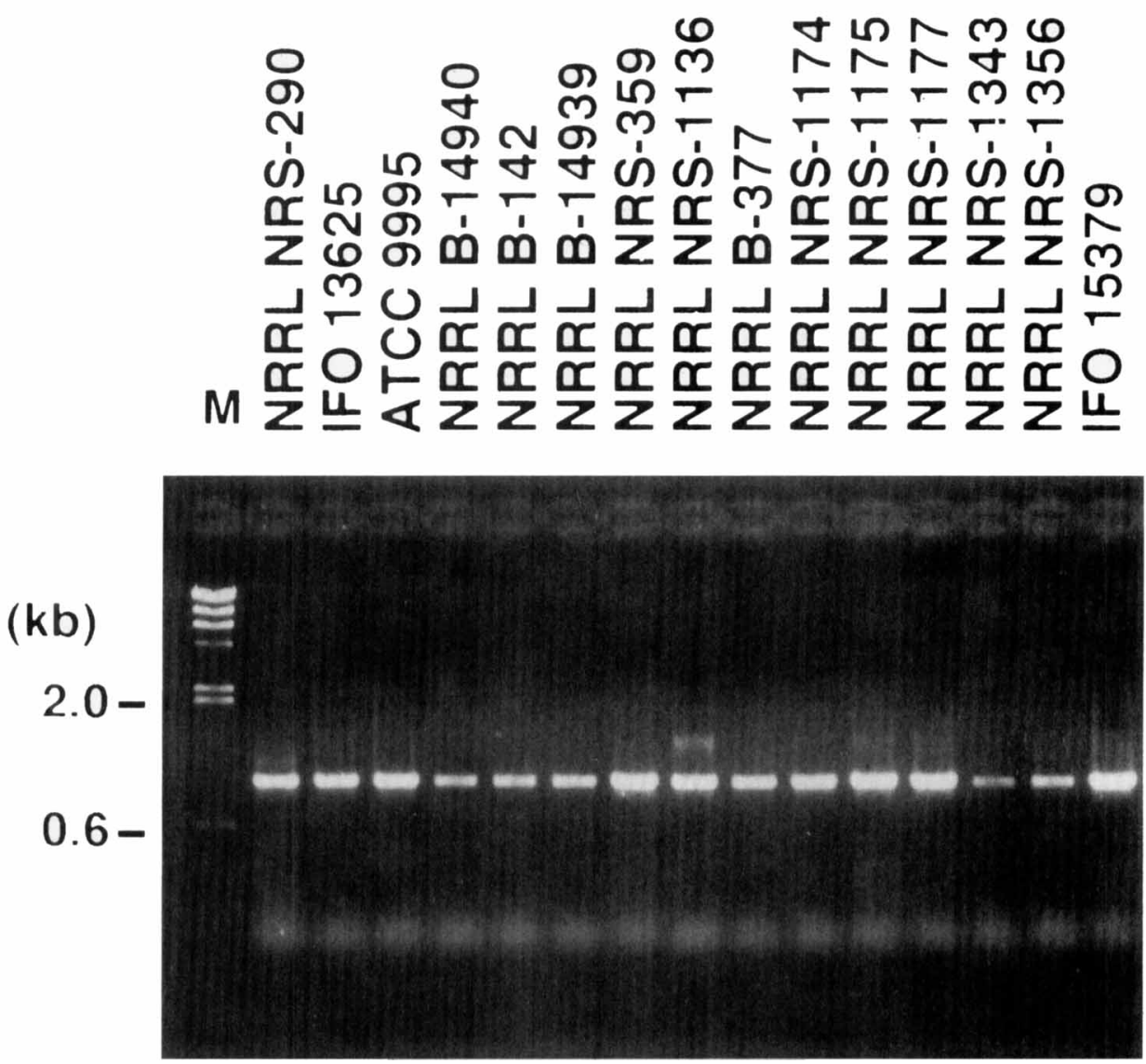

FIG. 1. Amplification of $16 \mathrm{~S}$ rRNA gene by PCR with detection primer PAEN515F and universal reverse primer 1377R. Lane M contained HindIII-digested $\lambda$ DNA as a molecular weight marker.

I, and strains NRRL B-142 ${ }^{\mathrm{T}}$ and NRRL B-14939 in group II were analyzed to determine their cellular fatty acid compositions and isoprenoid quinone compositions. Table 5 shows that all of the strains tested contained anteiso- $\mathrm{C}_{15.0}$ acids, which accounted for 36.4 to $57.8 \%$ of the total cellular fatty acids. All of the strains tested contained menaquinone 7 , which accounted for more than $93 \%$ of the total menaquinones.

\section{DISCUSSION}

The strains in $B$. circulans group 6 are aerobic rod-shaped organisms that produce ellipsoidal spores in swollen sporangia (Fig. 4B). A PCR amplification analysis of 16S rRNA gene fragments and a comparative analysis of the 16S rRNA gene sequence of NRRL NRS- $1356^{\mathrm{T}}$ revealed that group 6 belongs

TABLE 2. DNA base compositions and levels of DNA relatedness for strains of $B$. circulans group 6 and $P$. amylolyticus

\begin{tabular}{|c|c|c|c|c|c|c|c|c|}
\hline \multirow[b]{2}{*}{ Strain } & \multirow{2}{*}{$\begin{array}{c}\mathrm{G}+\mathrm{C} \\
\text { content } \\
(\mathrm{mol} \%)\end{array}$} & \multicolumn{7}{|c|}{$\%$ Reassociation with DNA from ${ }^{a}$ : } \\
\hline & & $\begin{array}{c}\text { NRRL } \\
\text { NRS-1175 }\end{array}$ & $\begin{array}{c}\text { NRRL } \\
{\text { NRS- } 1356^{\mathrm{T}}}\end{array}$ & $\begin{array}{c}\text { NRRL } \\
\text { NRS-290T }\end{array}$ & $\begin{array}{c}\text { IFO } \\
13625^{T}\end{array}$ & $\begin{array}{l}\text { NRRL } \\
\text { B-142 }\end{array}$ & $\begin{array}{l}\text { NRRL } \\
\text { B-14939 }\end{array}$ & $\begin{array}{l}\text { NRRL } \\
\text { B-377 }\end{array}$ \\
\hline NRRL NRS-1174 & 47.8 & 80 & 85 & 7 & 13 & 12 & 21 & 10 \\
\hline NRRL NRS-1175 & 48.0 & 100 & 100 & 21 & 20 & 19 & 25 & 2 \\
\hline NRRL NRS-1177 & 48.3 & 100 & 78 & 20 & 25 & 22 & 16 & 1 \\
\hline NRRL NRS-1343 & 47.7 & 100 & 79 & 19 & 22 & 18 & 20 & 17 \\
\hline NRRL NRS-1356 ${ }^{\mathrm{T}}$ & 48.1 & 100 & 100 & 19 & 33 & 15 & 23 & 16 \\
\hline IFO 15379 & 47.6 & 84 & 95 & 23 & 39 & 25 & 17 & 2 \\
\hline NRRL NRS- $290^{T}$ & 46.4 & 23 & 13 & 100 & 100 & 5 & 4 & 0 \\
\hline IFO $13625^{\mathrm{T}}$ & 46.3 & 20 & 19 & 72 & 100 & 1 & 3 & 5 \\
\hline NRRL B-14940 ${ }^{\mathrm{T}}$ & 46.6 & 19 & 24 & 88 & 100 & 1 & 5 & 16 \\
\hline ATCC $9995^{\mathrm{T}}$ & 46.5 & 21 & 17 & 100 & 100 & 6 & 3 & 3 \\
\hline NRRL B-142 ${ }^{\mathrm{T}}$ & 52.8 & 34 & 31 & 16 & 14 & 100 & 83 & 5 \\
\hline NRRL B-14939 & 52.5 & 28 & 22 & 18 & 25 & 100 & 100 & 15 \\
\hline NRRL NRS-359 & 53.2 & 30 & 26 & 15 & 16 & 100 & 95 & 3 \\
\hline NRRL NRS-1136 & 52.6 & 33 & 35 & 10 & 3 & 100 & 92 & 0 \\
\hline NRRL B-377 ${ }^{\mathrm{T}}$ & 48.9 & 35 & 40 & 30 & 23 & 26 & 28 & 100 \\
\hline
\end{tabular}

\footnotetext{
${ }^{a}$ Reassociation values are averages of two determinations; the maximum difference found between two determinations was $9 \%$.
} 
TABLE 3. DNA base compositions and levels of relatedness of selected B. circulans group 6 and $P$. amylolyticus strains to the type strains of previously recognized Paenibacillus species

\begin{tabular}{|c|c|c|c|c|c|}
\hline \multirow{2}{*}{ Strain } & \multirow{2}{*}{$\begin{array}{c}\mathrm{G}+\mathrm{C} \text { content } \\
(\mathrm{mol} \%)\end{array}$} & \multicolumn{4}{|c|}{$\%$ Reassociation with DNA from ${ }^{a}$ : } \\
\hline & & NRRL NRS- $1356^{\mathrm{T}}$ & NRRL NRS-290 & NRRL B-142 ${ }^{\mathrm{T}}$ & NRRL B-377 \\
\hline P. amylolyticus NRRL NRS- $290^{\mathrm{T}}$ & 46.4 & 13 & 100 & 5 & 0 \\
\hline P. amylolyticus NRRL B-142 & 52.8 & 31 & 16 & 100 & 5 \\
\hline P. amylolyticus NRRL B-377 ${ }^{\mathrm{T}}$ & 48.9 & 40 & 0 & 26 & 100 \\
\hline P. alginolyticus DSMZ $5050^{\mathrm{T}}$ & 45.7 & 7 & 18 & 23 & 21 \\
\hline$P$. alvei IFO $3343^{\mathrm{T}}$ & 45.6 & 10 & 3 & 13 & 15 \\
\hline P. apiarius NRRL NRS $-1438^{\mathrm{T}}$ & 52.3 & 3 & 10 & 21 & 15 \\
\hline P. azotofixans NRRL B-14372 & 46.7 & 7 & 28 & 20 & 4 \\
\hline P. chondroitinus DSMZ $5051^{\mathrm{T}}$ & 46.3 & 7 & 11 & 28 & 24 \\
\hline P. curdlanolyticus IFO $15724^{\mathrm{T}}$ & 53.1 & 10 & 23 & 26 & 8 \\
\hline P. glucanolyticus DSMZ $5162^{\mathrm{T}}$ & 48.3 & 3 & 22 & 10 & 36 \\
\hline P. kobensis IFO $15729^{\mathrm{T}}$ & 51.7 & 15 & 28 & 18 & 5 \\
\hline P. larvae subsp. pulvifaciens IFO $15408^{\mathrm{T}}$ & 44.2 & 4 & 10 & 6 & 9 \\
\hline P. lautus NRRL NRS- $666^{\mathrm{T}}$ & 50.4 & 10 & 26 & 18 & 86 \\
\hline$P$. macerans $\mathrm{JCM} 2500^{\mathrm{T}}$ & 51.8 & 2 & 6 & 25 & 5 \\
\hline P. macquariensis CIP $103269^{\mathrm{T}}$ & 40.2 & 3 & 5 & 8 & 9 \\
\hline P. pabuli NRRL NRS-924 ${ }^{\mathrm{T}}$ & 45.3 & 12 & 33 & 17 & 0 \\
\hline P. peoriae IFO $15541^{\mathrm{T}}$ & 46.2 & 8 & 19 & 2 & 0 \\
\hline P. polymyxa JCM $2507^{\mathrm{T}}$ & 46.8 & 1 & 24 & 21 & 13 \\
\hline P. thiaminolyticus $\mathrm{JCM} 8360^{\mathrm{T}}$ & 52.2 & 2 & 0 & 8 & 0 \\
\hline$P$. validus DSMZ $3037^{\mathrm{T}}$ & 51.7 & 7 & 9 & 11 & 0 \\
\hline
\end{tabular}

${ }^{a}$ Reassociation values are averages of two determinations; the maximum difference found between two determinations was $9 \%$.

to the genus Paenibacillus. This finding is supported by the DNA base compositions and other chemosystematic characteristics. For example, the $\mathrm{G}+\mathrm{C}$ content, $48 \mathrm{~mol} \%$, falls within the range exhibited by Paenibacillus species ( 45 to $54 \mathrm{~mol} \%$ ) $(2,19)$. Also, the anteiso- $\mathrm{C}_{15: 0}$ fatty acid content $(56$ to $57 \%$ of the total fatty acids) and the presence of menaquinone 7 as the principal quinone are characteristic of the genus Paenibacillus $(2,19)$.

Group 6 strains are phenotypically distinguishable from the closely related Paenibacillus species, as shown in Table 6. DNA relatedness and phenotypic characterization analyses showed that group 6 is a genetically distinct taxon and that it merits recognition as a new species, for which the name Paenibacillus illinoisensis is proposed.

Four strains (NRRL NRS-290 ${ }^{\mathrm{T}}\left[=\right.$ NRRL B-377 ${ }^{\mathrm{T}}$, NRRL NRS-359, NRRL NRS-1136, and NRRL B-142 ${ }^{\mathrm{T}}$ ) were identified as $P$. amylolyticus strains (formerly assigned to $B$. amylolyticus) on the basis of their DNA reassociation values, the $\mathrm{G}+\mathrm{C}$ contents of their DNAs, and their phenotypic characteristics $(12,13)$. DNA relatedness studies and a phenotypic reexamination of the $P$. amylolyticus strains revealed the presence of three separate taxa in this species (Table 2). The group I strains were identified as members of $P$. amylolyticus sensu stricto, and the single group III strain was identified as $P$. lautus. Group I strains NRRL B-14940 ${ }^{\mathrm{T}}$, IFO $13625^{\mathrm{T}}$, NRRL NRS-290 ${ }^{\mathrm{T}}$, and ATCC $9995^{\mathrm{T}}$ and group III strain NRRL B$377^{\mathrm{T}}$ were purportedly derived from the same strain, strain NRS $-290^{\mathrm{T}}$. Therefore, the anomalous identification of NRRL B- $377^{\mathbf{T}}$ as $P$. lautus probably resulted from mislabeling in the culture collection. Strains NRRL B-142 ${ }^{\mathrm{T}}$, NRRL B-14939, NRRL NRS-359, and NRRL NRS-1136 formed group II, another genetically and phenotypically distinct taxon. This confusing result was probably due to erroneous identification in previous reports $(12,13)$.

Taxonomic reevaluation has changed $P$. amylolyticus into a taxon with four strains that have a common provenance, namely, strain NRS- $290^{\mathrm{T}}$. An emended description of $P$. amylolyticus resulting from our study is given below.

16S rRNA gene analysis revealed that group II strain NRRL
B-142 ${ }^{\mathrm{T}}$ was closely related to Paenibacillus species (Fig. 2). The DNA relatedness, phenotypic characterization, and phylogenetic analyses revealed that group II is a genetically distinct taxon that represents a new species whose members have $\mathrm{G}+\mathrm{C}$

TABLE 4. Distinctive phenotypic characteristics of $B$. circulans group 6 and $P$. amylolyticus group I, II, and III strains

\begin{tabular}{|c|c|c|c|c|}
\hline \multirow[b]{2}{*}{ Characteristic } & \multicolumn{4}{|c|}{$\%$ of positive strains } \\
\hline & $\begin{array}{c}\text { Group } 6 \\
\text { (P. illinoisensis) } \\
(n=6)^{a}\end{array}$ & $\begin{array}{c}\text { Group I } \\
\text { (P. amylolyticus } \\
\text { sensu stricto) } \\
(n=4)\end{array}$ & $\begin{array}{c}\text { Group II } \\
(P . \text { chibensis }) \\
(n=4)\end{array}$ & $\begin{array}{l}\text { Group III } \\
(P . \text { lautus }) \\
(n=5)\end{array}$ \\
\hline \multicolumn{5}{|l|}{ Colony color } \\
\hline Brownish yellow & 0 & 0 & 100 & 80 \\
\hline Grayish white & 100 & 100 & 0 & 20 \\
\hline Anaerobic growth & 100 & 100 & 0 & 100 \\
\hline Nitrate reduction & 0 & 100 & 100 & 100 \\
\hline \multicolumn{5}{|l|}{ Utilization of: } \\
\hline Acetate & 100 & 0 & 0 & 0 \\
\hline Ammonium & 100 & 0 & 100 & 0 \\
\hline Nitrate & 100 & 0 & 100 & 100 \\
\hline \multicolumn{5}{|l|}{ Hydrolysis of: } \\
\hline Casein & $100(w)^{b}$ & $100(w)$ & 0 & 0 \\
\hline Gelatin & 100 & 100 & 0 & 100 \\
\hline Starch & 100 & 100 & 100 & 100 \\
\hline Tween 20 & 100 & 100 & 0 & 0 \\
\hline Tween 60 & 0 & 100 & 0 & 0 \\
\hline Growth at $40^{\circ} \mathrm{C}$ & 100 & 0 & 100 & 100 \\
\hline \multicolumn{5}{|l|}{$\begin{array}{l}\text { Acid produced } \\
\text { from: }\end{array}$} \\
\hline Glycerol & 100 & 100 & 0 & 100 \\
\hline D-Mannose & 100 & 100 & 0 & 100 \\
\hline Raffinose & 100 & 0 & 0 & 0 \\
\hline $\begin{array}{c}\text { Resistance to lyso- } \\
\text { zyme }(0.01 \%)\end{array}$ & 33 & 0 & 100 & 100 \\
\hline $\begin{array}{l}\text { Reaction of litmus } \\
\text { in litmus milk }\end{array}$ & 100 & 0 & 100 & 40 \\
\hline
\end{tabular}

${ }^{a} n$ is the number of strains examined.

${ }^{b} \mathrm{w}$, weakly positive. 


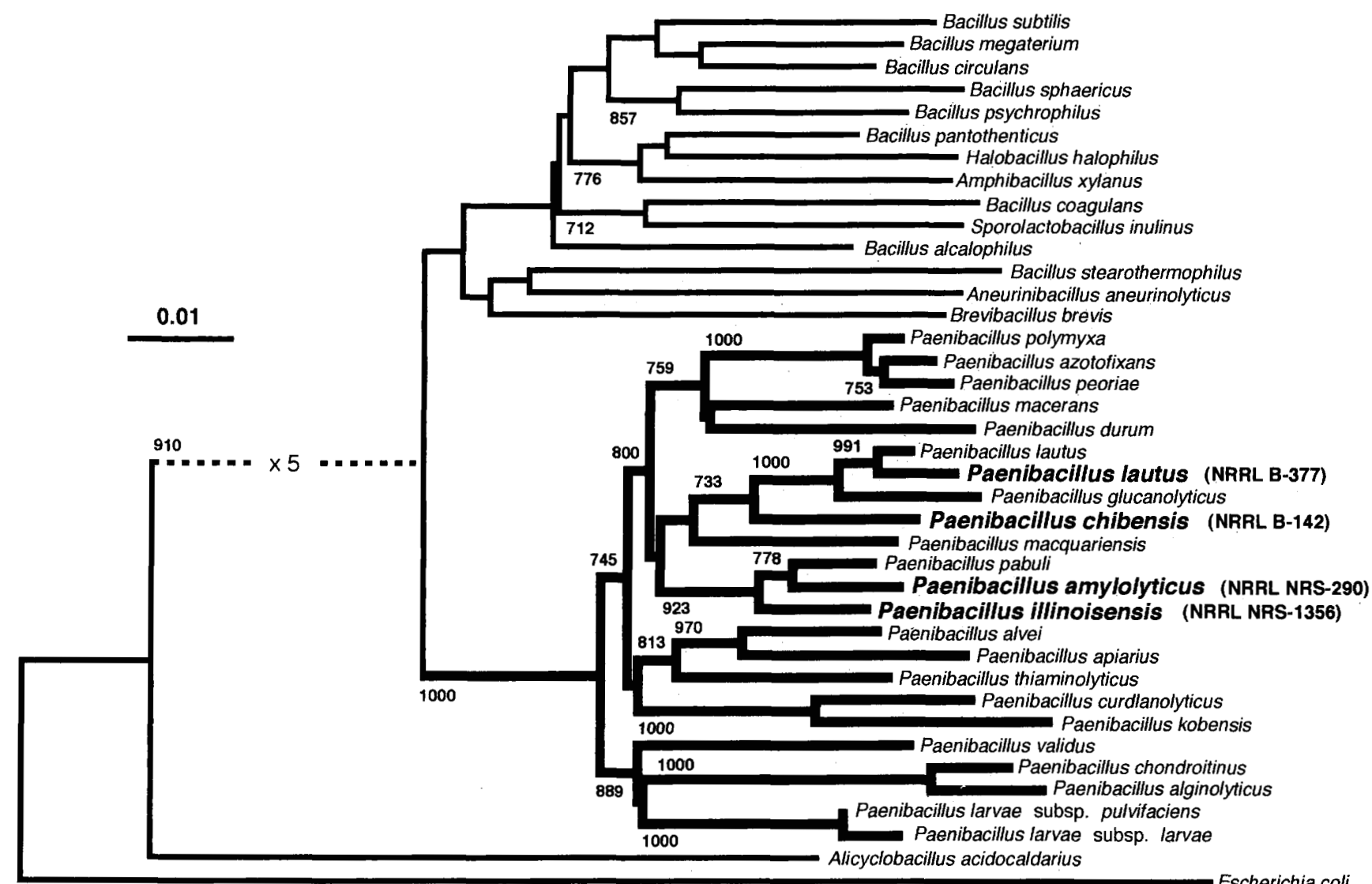

FIG. 2. Phylogenetic relationships of Paenibacillus species and some aerobic, rod-shaped, endospore-forming bacteria based on $16 \mathrm{~S}$ rRNA gene sequences. The branching pattern was generated by the neighbor-joining method. The numbers indicate bootstrap values greater than 700 . The boldface lines and boldface type indicate the cluster consisting of Paenibacillus species and the strains sequenced in this study, respectively. Bar $=0.01$ nucleotide substitution per site.

contents ranging from 52.5 to 53.2 mol\%. Group II encompasses three strains (NRRL B-142 ${ }^{\mathrm{T}}$, NRRL B-14939, and NRRL NRS-1136) which have a common origin (PCI 221) and strain NRRL NRS-359. Although group II is represented by only two strains, frequent use of these organisms in antibiotic assays encourages recognition of them as a new species, whose proposed name is Paenibacillus chibensis.

Previously, we described a simple method for identifying Brevibacillus and Aneurinibacillus strains by PCR amplification of $16 \mathrm{~S}$ rRNA gene fragments with a specific detection primer (18). The usefulness of this method for identification of Paenibacillus strains was confirmed in another study (19) and in this study. The detection primer, primer PAEN515F, was highly specific for identification of the genus Paenibacillus.

Emended description of Paenibacillus amylolyticus (Nakamura 1984) Ash, Priest, and Collins 1993. Cells are rods that are 0.7 to 0.9 by 3.0 to $5.0 \mu \mathrm{m}$. Gram positive. Motile with peritrichous flagella. Ellipsoidal spores are formed in swollen sporangia (Fig. 4A). Colonies are flat, smooth, circular, and entire. No soluble pigment is produced on nutrient agar.

Facultatively anaerobic.

Catalase positive and oxidase negative.

Acetylmethylcarbinol is not produced (as determined by the Voges-Proskauer reaction). The $\mathrm{pH}$ in Voges-Proskauer broth is 5.2 .

Hydrogen sulfide, indole, dihydroxyacetone, and lecithinase (as determined by the egg yolk reaction) are not produced.

Nitrate is reduced to nitrite.

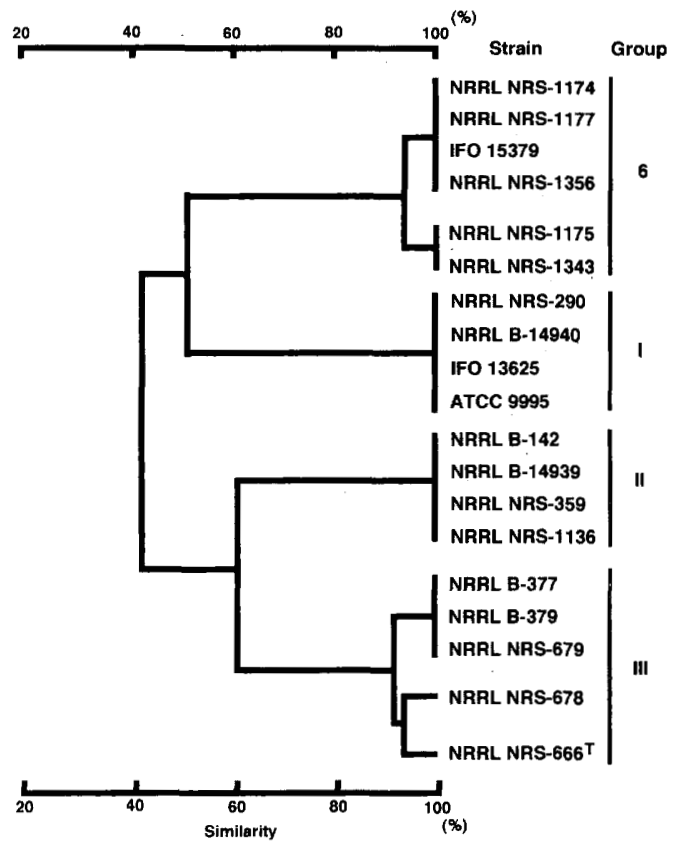

FIG. 3. Phenotypic relationships among strains of $B$. circulans group 6 and $P$. amylolyticus group I, II, and III strains. The dendrogram was produced by using the simple matching coefficient and the unweight pair group arithmetic average algorithm. 
TABLE 5. Cellular fatty acid compositions of $B$. circulans group 6 and $P$. amylolyticus group I, II, and III strains

\begin{tabular}{|c|c|c|c|c|c|c|c|c|c|c|c|}
\hline \multirow{3}{*}{ Strain } & \multicolumn{11}{|c|}{$\%$ of total cellular fatty acids } \\
\hline & \multicolumn{9}{|c|}{ Saturated acids } & \multicolumn{2}{|c|}{ Unsaturated acids } \\
\hline & $\mathrm{C}_{14: 0}$ & $C_{15: 0}$ & $\mathrm{C}_{16: 0}$ & iso- $\mathrm{C}_{14: 0}$ & iso- $C_{15: 0}$ & iso- $\mathrm{C}_{16: 0}$ & iso- $\mathrm{C}_{17: 0}$ & $\begin{array}{c}\text { anteiso- } \\
\mathrm{C}_{15: 0}\end{array}$ & $\begin{array}{c}\text { anteiso- } \\
\mathrm{C}_{17: 0}\end{array}$ & $\mathrm{C}_{16: 1} \omega 11$ & iso- $C_{17: 1} \omega 10$ \\
\hline \multicolumn{12}{|l|}{ Group 6 ( $P$. illinoisensis $)$ strains } \\
\hline NRRL NRS-1175 & 1.6 & 0.3 & 24.3 & 1.5 & 1.6 & 6.6 & 1.2 & 55.9 & 5.7 & $\mathrm{ND}^{a}$ & ND \\
\hline NRRL NRS- $1356^{\mathrm{T}}$ & 2.0 & 1.0 & 24.7 & 1.8 & 1.5 & 6.3 & 1.4 & 56.6 & 4.9 & ND & ND \\
\hline \multicolumn{12}{|l|}{ Group I ( $P$. amylolyticus sensu stricto) strains } \\
\hline NRRL NRS-290 ${ }^{\mathrm{T}}$ & 2.9 & 0.5 & 12.8 & 2.3 & 2.0 & 9.0 & 3.5 & 46.2 & 2.2 & 0.1 & ND \\
\hline IFO $13625^{\mathrm{T}}$ & 2.4 & 0.8 & 13.7 & 2.6 & 1.7 & 8.6 & 2.3 & 43.0 & 2.0 & 0.2 & 1.2 \\
\hline \multicolumn{12}{|l|}{ Group II ( $P$. chibensis) strains } \\
\hline NRRL B-142 $2^{\mathrm{T} b}$ & 0.3 & 0.6 & 5.3 & 0.8 & 4.0 & 12.2 & 3.2 & 57.8 & 14.3 & ND & ND \\
\hline NRRL B-14939 & 0.4 & 0.6 & 9.8 & 0.5 & 2.9 & 10.7 & 3.6 & 53.7 & 15.2 & ND & 0.2 \\
\hline Group III ( $P$. lautus) strain NRRL B-377 & 0.6 & 0.5 & 20.1 & 0.2 & 2.9 & 4.1 & 5.8 & 36.9 & 11.5 & 0.5 & 1.0 \\
\hline
\end{tabular}

"ND, not detected.

${ }^{b}$ Data from reference 19 .

Casein, gelatin, starch, Tween 20 , and Tween 60 are hydrolyzed (hydrolysis of casein is weakly positive). DNA, Tween 80 , urea, and hippurate are not hydrolyzed.

Tyrosine is not decomposed.

Phenylalanine is not deaminated.

Citrate, propionate, acetate, fumarate, L-malate, lactate, succinate, L-glutamate, L-asparatate, alginate, gluconate, $\alpha$-ketoglutarate, malonate, and tartrate are not utilized.

Nitrate and ammonium are utilized.

No change occurs in litmus milk.

Growth occurs at temperatures between 10 and $40^{\circ} \mathrm{C}$ and at $\mathrm{pH} 4.5$ to 9.0. Optimum growth occurs at $37^{\circ} \mathrm{C}$ and at $\mathrm{pH} 7.0$. Growth does not occur at temperatures lower than $10^{\circ} \mathrm{C}$ or greater than $40^{\circ} \mathrm{C}$.

Growth occurs in the presence of $2 \% \mathrm{NaCl}$. Growth is inhibited by $5 \% \mathrm{NaCl}, 0.02 \%$ sodium azide, and $0.001 \%$ lysozyme.

Acid but no gas is produced from D-glucose, L-arabinose, D-fructose, D-galactose, maltose, sucrose, D-xylose, trehalose, glycerol, D-mannitol, D-cellobiose, D-ribose, salicin, D-mannose, melibiose, inositol, inulin, and starch. Neither acid nor gas is produced from lactose, D-sorbitol, L-sorbose, L-rhamnose, raffinose, and adonitol.

The major fatty acids are anteiso- $\mathrm{C}_{15: 0}$ and $\mathrm{C}_{16: 0}$. The major quinone is menaquinone 7.

The $\mathrm{G}+\mathrm{C}$ content ranges from 46.3 to $46.6 \mathrm{~mol} \%$.

The type strain is NRRL NRS-290, which was isolated by K. F. Kellerman. The type strain has been deposited in the Culture Collection of the Research Laboratory of Higeta Shoyu Co., Ltd., Chiba, Japan as strain HSCC 434 (= JCM 9906 = IFO 15957).

Description of Paenibacillus illinoisensis sp. nov. Paenibacillus illinoisensis (il. li. nois. en'sis. M.L. adj. illinoisensis, referring to Illinois, the state where Microbial Properties Research, National Center for Agricultural Utilization Research, Agricultural Research Service, U.S. Department of Agriculture, is located). Cells are rods that are 0.5 to 0.8 by 3.0 to $5.0 \mu \mathrm{m}$. Gram positive. Motile with peritrichous flagella. Ellipsoidal spores are formed in swollen sporangia (Fig. 4B). Colonies are flat, smooth, circular, entire, and yellowish gray. No soluble pigment is produced on nutrient agar.

Facultatively anaerobic.

Catalase positive and oxidase negative.

Acetylmethylcarbinol is not produced (as determined by the Voges-Proskauer reaction). The $\mathrm{pH}$ in Voges-Proskauer broth is 5.0 to 5.2 .
Hydrogen sulfide, indole, dihydroxyacetone, and lecithinase (as determined by the egg yolk reaction) are not produced. Nitrate is not reduced to nitrite.

Casein, gelatin, starch, and Tween 20 are hydrolyzed (hydrolysis of casein is weakly positive). DNA, Tween 60 , Tween 80 , urea, and hippurate are not hydrolyzed.

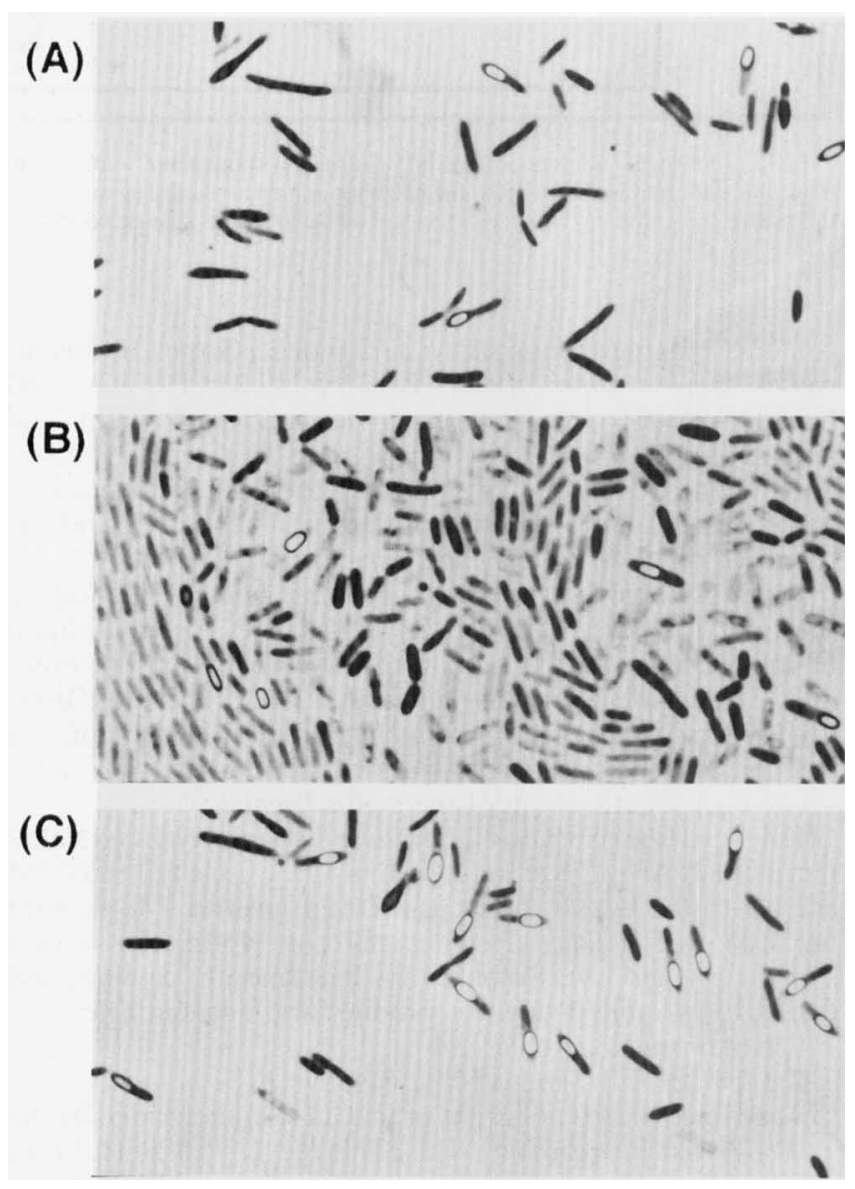

FIG. 4. Phase-contrast micrographs of sporulating cells of three species. (A) P. amylolyticus NRRL NRS-290T. (B) $P$. illinoisensis NRRL NRS-1356 ${ }^{\mathrm{T}}$. (C) $P$. chibensis NRRL B-142 ${ }^{\mathrm{T}}$. Cells were cultured on tryptic soy agar plates for days at $37^{\circ} \mathrm{C}$. 


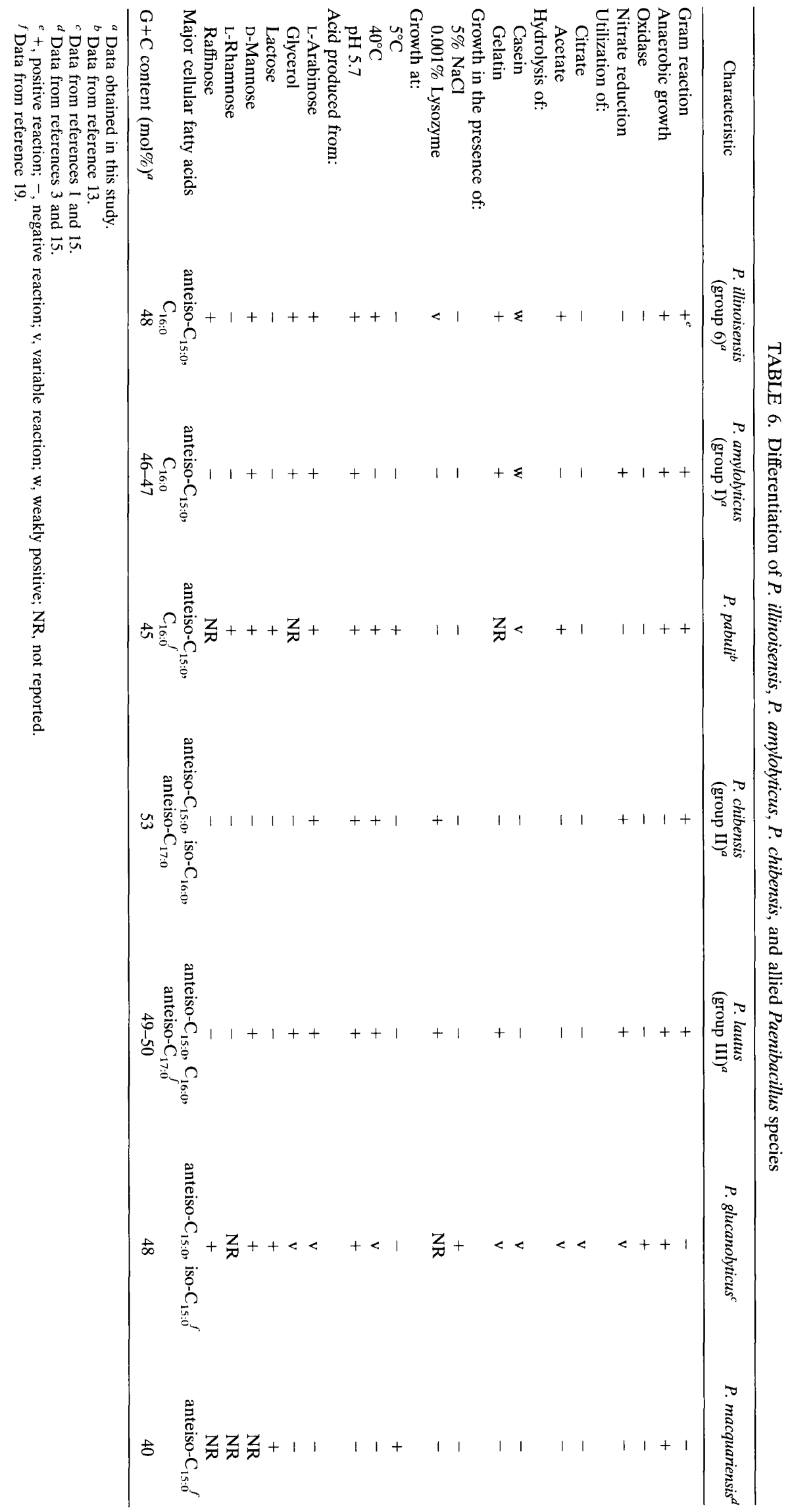


Tyrosine is not decomposed.

Phenylalanine is not deaminated.

Acetate is utilized, and citrate, propionate, fumarate, L-malate, lactate, succinate, L-glutamate, L-asparatate, alginate, gluconate, $\alpha$-ketoglutarate, malonate, and tartrate are not utilized.

Nitrate and ammonium are utilized.

Litmus is reduced in litmus milk.

Growth occurs at temperatures between 10 and $50^{\circ} \mathrm{C}$ and at $\mathrm{pH} 4.5$ to 9.0. Optimum growth occurs at $37^{\circ} \mathrm{C}$ and at $\mathrm{pH} 7.0$.

Growth occurs in the presence of $2 \% \mathrm{NaCl}$. Growth is inhibited by $5 \% \mathrm{NaCl}$ and by $0.02 \%$ sodium azide. Some strains can grow in the presence of $0.001 \%$ lysozyme.

Acid but no gas is produced from D-glucose, L-arabinose, D-fructose, D-galactose, maitose, sucrose, D-xylose, trehalose, glycerol, D-mannitol, D-cellobiose, D-ribose, salicin, D-mannose, melibiose, raffinose, inositol, inulin, and starch. Neither acid nor gas is produced from lactose, D-sorbitol, L-sorbose, L-rhamnose, and adonitol.

The major fatty acids are anteiso- $\mathrm{C}_{15: 0}$ and $\mathrm{C}_{16: 0}$. The major quinone is menaquinone 7 .

The $\mathrm{G}+\mathrm{C}$ content ranges from 47.6 to $48.3 \mathrm{~mol} \%$. The $\mathrm{G}+\mathrm{C}$ content of the type strain is $48.1 \mathrm{~mol} \%$.

The type strain is NRRL NRS-1356, which was isolated from soil by F. E. Clark. The type strain has been deposited in the Culture Collection of the Research Laboratory of Higeta Shoyu Co., Ltd., Chiba, Japan as strain HSCC 309 (= JCM 9907 = IFO 15959).

Description of Paenibacillus chibensis sp. nov. Paenibacillus chibensis (chi.ben'sis. M.L. adj. chibenesis, referring to Chiba, a Japanese prefecture where the Research Laboratory of Higeta Shoyu Co., Ltd., is located). Cells are rods that are 0.5 to 0.8 by 3.0 to $5.0 \mu \mathrm{m}$. Gram positive. Motile by means of peritrichous flagella. Ellipsoidal spores are formed in swollen sporangia (Fig. 4C). Colonies are flat, smooth, circular, entire, and brownish yellow. No soluble pigment is produced on nutrient agar.

Strictly aerobic.

Catalase positive and oxidase negative.

Acetylmethylcarbinol is not produced (as determined by the Voges-Proskauer reaction). The $\mathrm{pH}$ in Voges-Proskauer broth ranges from 4.6 to 4.7 .

Hydrogen sulfide, indole, dihydroxyacetone, and lecithinase (as determined by the egg yolk reaction) are not produced.

Nitrate is reduced to nitrite.

Starch is hydrolyzed. Casein, gelatin, DNA, Tween 20 ,

Tween 60, Tween 80, urea, and hippurate are not hydrolyzed.

Tyrosine is not decomposed. Phenylalanine is not deaminated.

Citrate, propionate, acetate, fumarate, L-malate, lactate, succinate, L-glutamate, L-asparatate, alginate, gluconate, $\alpha$-ketoglutarate, malonate, and tartrate are not utilized.

Nitrate and ammonium are utilized.

No change occurs in litmus milk.

Growth occurs at temperatures between 10 and $50^{\circ} \mathrm{C}$ and at 4.5 to 9.0. Optimum growth occurs at $37^{\circ} \mathrm{C}$ and at $\mathrm{pH} 7.0$.

Growth occurs in the presence of $2 \% \mathrm{NaCl}$ and $0.001 \%$ lysozyme. Growth is inhibited by $5 \% \mathrm{NaCl}$ and by $0.02 \%$ sodium azide.

Acid but no gas is produced from D-glucose, L-arabinose, D-fructose, D-galactose, maltose, sucrose, D-xylose, trehalose, D-mannitol, D-cellobiose, D-ribose, salicin, melibiose, inositol, inulin, and starch. Neither acid nor gas is produced from lactose, glycerol, D-sorbitol, L-sorbose, D-mannose, L-rhamnose, and adonitol.

The major fatty acids are anteiso- $\mathrm{C}_{15: 0}$, anteiso- $\mathrm{C}_{17: 0}$, and iso- $\mathrm{C}_{16: 0}$. The major quinone is menaquinone 7 .
The $\mathrm{G}+\mathrm{C}$ content ranges from 52.5 to $53.2 \mathrm{~mol} \%$. The $\mathrm{G}+\mathrm{C}$ content of the type strain is $52.8 \mathrm{~mol} \%$.

The type strain is NRRL B-142, which has been deposited in the Culture Collection of the Research Laboratory of Higeta Shoyu Co., Ltd., Chiba, Japan as strain HSCC 442 (= JCM $9905=$ IFO 15958).

\section{ACKNOWLEDGMENTS}

We thank H. Shimada, R. Wakamatsu, K. Sano, and N. Tanaka for technical assistance.

\section{REFERENCES}

1. Alexander, B., and F. G. Priest. 1989. Bacillus glucanolyticus, a new specie that degrades a variety of $\beta$-glucans. Int. J. Syst. Bacteriol. 39:112-115.

2. Ash, C., F. G. Priest, and M. D. Collins. 1993. Molecular identification of rRNA group 3 bacilli (Ash, Farrow, Wallbanks, and Collins) using a PCR probe test. Proposal for the creation of a new genus Paenibacillus. Antonie van Leeuwenhoek 64:253-260.

3. Claus, D., and R. C. W. Berkeley. 1986. Genus Bacillus Cohn 1872, p. 1105-1140. In P. H. A. Sneath, N. S. Mair, M. E. Sharpe, and J. G. Holt (ed.) Bergey's manual of systematic bacteriology, vol. 2. The Williams and Wilkin Co., Baltimore, $\mathrm{Md}$

4. Ezaki, T., Y. Hashimoto, and E. Yabuuchi. 1989. Fluorometric deoxyribonucleic acid-deoxyribonucleic acid hybridization in microdilution wells as an alternative to membrane filter hybridization in which radioisotopes are used to determine genetic relatedness among bacterial strains. Int. J. Syst. Bacteriol. 39:224-229.

5. Felsenstein, J. 1985. Confidence limits on phylogenies: an approach using the bootstrap. Evolution 39:783-791.

6. Fox, G. E., J. Wisotzkey, and P. Jurtshuk, Jr. 1992. How close is close: 16S rRNA sequence identity may not be sufficient to guarantee species identity. Int. J. Syst. Bacteriol. 42:166-170.

7. Gordon, R. E., W. C. Hynes, and C. H. N. Pang. 1973. The genus Bacillus. Agricultural Handbook no. 427. U.S. Department of Agriculture, Washing ton, D.C.

8. Heyndrickx, M., K. Vandemeulebroecke, P. Scheldeman, K. Kersters, P. D Vos, N. A. Logan, A. M. Aziz, N. Ali, and R. C. W. Berkeley. 1996. A polyphasic reassessment of the genus Paenibacillus, reclassification of Bacillus lautus (Nakamura 1984) as Paenibacillus lautus comb. nov. and Bacillus peoriae (Montefusco et al. 1993) as Paenibacillus peoriae comb. nov., and emended description of $P$. lautus and $P$. peoriae. Int. J. Syst. Bacteriol. 46: 988-1003.

9. Kimura, M. 1980. A simple method for estimating evolutionary rates of base substitutions through comparative studies of nucleotide sequences. J. Mol. Evol. 16:111-120

10. Komagata, K., and K. Suzuki. 1987. Lipid and cell-wall analysis in bacterial systematics. Methods Microbiol. 19:161-207.

11. Nakamura, L. K., and J. Swezey. 1983. Taxonomy of Bacillus circulan Jordan 1890: base composition and reassociation of deoxyribonucleic acid. Int. J. Syst. Bacteriol. 33:46-52.

12. Nakamura, L. K., and J. Swezey. 1983. Deoxyribonucleic acid relatedness of Bacillus circulans Jordan 1890 strains. Int. J. Syst. Bacteriol. 33:703-708.

13. Nakamura, L. K. 1984. Bacillus amylolyticus sp. nov., nom. rev., Bacillus lautus sp. nov., nom. rev., Bacillus pabuli sp. nov., nom. rev., and Bacillus validus sp. nov., nom. rev. Int. J. Syst. Bacteriol. 34:224-226.

14. Nakamura, L. K. 1987. Bacillus alginolyticus sp. nov. and Bacillus chondroitinus sp. nov., two alginate-degrading species. Int. J. Syst. Bacteriol. 37:284-286.

15. Priest, F. G., M. Goodfellow, and C. Todd. 1988. A numerical classification of the genus Bacillus. J. Gen. Microbiol. 134:1847-1882.

16. Saito, N., and M. Nei. 1987. The neighbor-joining method: a new method for reconstructing phylogenetic trees. Mol. Biol. Evol. 4:406-425.

17. Sanger, F., S. Nicklen, and A. R. Coulson. 1977. DNA sequencing with chain-terminating inhibitors. Proc. Natl. Acad. Sci. USA 74:5463-5467.

18. Shida, O., H. Takagi, K. Kadowaki, and K. Komagata. 1996. Proposal for two new genera, Brevibacillus gen. nov. and Aneurinibacillus gen. nov. Int. J. Syst. Bacteriol. 46:939-946.

19. Shida, O., H. Takagi, K. Kadowaki, L. K. Nakamura, and K. Komagata 1997. Transfer of Bacillus alginolyticus, Bacillus chondroitinus, Bacillus curd lanolyticus, Bacillus glucanolyticus, Bacillus kobensis, and Bacillus thiaminolyticus to the genus Paenibacillus and emended description of the genus Paenibacillus. Int. J. Syst. Bacteriol. 47:289-298.

20. Takagi, H., O. Shida, K. Kadowaki, K. Komagata, and S. Udaka. 1993. Characterization of Bacillus brevis with descriptions of Bacillus migulanus sp. nov., Bacillus choshinensis sp. nov., Bacillus parabrevis sp. nov., and Bacillus galactophilus sp. nov. Int. J. Syst. Bacteriol. 43:221-231.

21. Thompson, J. D., D. G. Higgins, and T. J. Gibson. 1994. CLUSTAL W improving the sensitivity of progressive multiple sequence alignment through sequence weighting, position-specific gap penalties and weight matrix choice. Nucleic Acids Res. 22:4673-4680. 